\title{
Student satisfaction level among allied health sciences students at King Edward Medical University
}

\author{
Afisa Bashir ${ }^{1}$, Shahzaib Ahmad ${ }^{2}$, Muhammad Zeeshan Sarwar ${ }^{3}$, Syed Asghar Naqi $^{4}$ \\ ${ }^{1}$ Allied Health Sciences, King Edward Medical University Lahore, Pakistan \\ ${ }^{2}$ King Edward Medical University Lahore, Pakistan \\ ${ }^{3,4}$ East Surgical Ward, Mayo Hospital Lahore, Pakistan
}

\begin{tabular}{l} 
Article Info \\
\hline Article history: \\
Received Aug 13, 2020 \\
Revised Dec 3, 2020 \\
Accepted Jan 2, 2021 \\
\hline
\end{tabular}

\section{Keywords:}

Academic environment Administrative services Allied health sciences Student satisfaction

\begin{abstract}
The purpose of this study was to evaluate student satisfaction with their program, academic environment and administrative services in terms of its effectiveness on their professional attitudes, lives and career. A total of 261 students of allied health sciences program at King Edward Medical University, were examined in terms of personal satisfaction by means of a specifically designed student satisfaction survey. A qualitative analysis approach was used to interpret the data generated by a three-part survey form circulated to the four proceeding sessions of allied health sciences program and satisfaction of students in 12 major disciplines was evaluated. The data was entered in statistical product and service solutions (SPSS) version 22 using quantitative variables and descriptive statistics including frequency distribution tables and diagrams. The study revealed a student satisfaction of only $22.1 \%$ with their program with different levels of recommendation in different sub-disciplines. A total of $20.9 \%$ students agreed to the library facilities, $53.9 \%$ with computer lab, $35 \%$ with administrative support, $29.6 \%$ with sports facilities and $49 \%$ with teaching methodologies. The present study concludes that most of the students had little satisfaction concerning their field of study. So, it is necessary to make an attempt for continuous development of quality services.
\end{abstract}

This is an open access article under the CC BY-SA license.

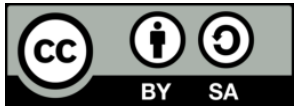

\section{Corresponding Author:}

Shahzaib Ahmad

King Edward Medical University, Lahore, Pakistan

Email: shahzaib.ahmad@kemu.edu.pk

\section{INTRODUCTION}

Student satisfaction is the subjective perceptions, on students' part, of how well a learning environment supports academic success [1]. This is one of the factors that effects the quality and effectiveness of any university program as well as student's outcome and graduation rate. It has been widely recognized as an important quality indicator of the students learning and teaching experience [2].

Since the students' satisfaction has been associated with their later professional attitudes, career commitment and retention, professional education faculties should be concerned with student's satisfaction as an outcome of the educational process. It has been recognized as the major factor of competition among universities [3, 4] as it can help an institute to improve its programs and services, remain accountable to student, and continue to be competitive [5]. Much focus has been laid on student satisfaction surveys revealing a student satisfaction of $62 \%$ with their program whereas satisfaction with teaching methods and styles was $67 \%$. However, local data is quite scarce. A student satisfaction level of $60.8 \%$ was observed in different physiotherapy institutes of Pakistan, with higher student-teacher relationship satisfaction $(71.2 \%)$ and lower curriculum satisfaction $(21.7 \%)$. A total of $40.4 \%$ students joined this course on their personal 
choice [4]. King Edward Medical University (KEMU) is one of the oldest medical institute in Pakistan. Institute of Allied health sciences started in 2008, offering 4-year bachelor's degree in 12 disciplines. Quite a few batches have graduated from this institute, but no survey has been conducted so far regarding student satisfaction with their program, academic environment, administration and co-curricular activities. This study is being conducted to evaluate Allied health sciences programme of KEMU.

\section{RESEARCH METHOD}

This cross-sectional descriptive study was conducted at Institute of Allied Health Sciences, KEMU, Lahore from December 2015 to February 2016. Sample size of 370 students was calculated by using 95\% confidence level, $5 \%$ margin of error with expected student satisfaction percentage of $40.4 \%$ with quality of teaching [4]. List of students was obtained from registrar office of the KEMU. A total of 400 students currently enrolled with the Institute of Allied Health Sciences, KEMU were included in the study. Students who were absent due to educational leaves were excluded. All the researchers obliged themselves to practice in accordance to Helsinki Declaration 1964 and its later amendments. The study was approved by the institutional review board of KEMU.

The questionnaire was prepared after extensive literature search. Later on, it was validated by distributing it to the academic members and subject specialist for its content validity. Students' satisfaction was evaluated in terms of six parameters including facilities provided in library, computer lab, classroom, sports along with administrative support and teaching methodology. Response was categorized as strongly agree, agree, disagree, strongly disagree and not sure.

A written informed consent was taken from the participants. Participants filled the pre-designed questionnaire and handed over to the researcher. Participants who didn't send back the filled questionnaire were given two reminders and then excluded from the study. All collected data entered into SPSS version 20. Tabulation of the demographic variables along with frequencies of the responses were done. Cross tabulation of academic activities with different disciplines of allied health sciences and difference of program me recommendation among different disciplines were also tabulated.

\section{RESULTS}

Out of 400 , only 261 completed the questionnaires with the response rate of $65 \%$. Mean age of the respondents was $20.82 \pm 1.34$ years. Out of 261participants, $25(9.6 \%)$ were male and $236(90.4 \%)$ were female is shown in Table 1. A total of $164(62.8 \%)$ students were aware of the location though $179(68.8 \%)$ students never used the library facility. A total of $231(88.8 \%)$ students didn't even know the university librarian. However, students were quite eager to use the computer lab as 237 (91.9\%) students being aware of the lab location and $241(92.5 \%)$ students frequently visiting the lab.

\begin{tabular}{lc}
\multicolumn{2}{c}{ Table 1. Demographic profile of students } \\
\hline \multicolumn{2}{c}{ Age (years) } \\
\hline Gender & $20.82 \pm 1.34$ \\
Male & $25(9.6 \%)$ \\
Female & $236(90.4 \%)$ \\
Disciplines & \\
Operation theater technology & $48(18.4 \%)$ \\
Medical lab technology & $37(14.2 \%)$ \\
Medical imaging technology & $35(13.4 \%)$ \\
Orthotics and Prosthetics & $23(8.8 \%)$ \\
Dental technology & $22(8.4 \%)$ \\
Hearing sciences technology & $18(6.9 \%)$ \\
Psychological sciences & $16(6.1 \%)$ \\
Anesthesia technology & $15(5.7 \%)$ \\
Renal dialysis technology & $14(5.4 \%)$ \\
Radiation therapy technology & $14(5.4 \%)$ \\
Speech therapy technology & $10(3.8)$ \\
Cardiac perfusion technology & $9(3.4 \%)$ \\
Programme year & \\
$1^{\text {st } y e a r ~}$ & $72(27.6 \%)$ \\
$2^{\text {nd }}$ year & $76(29.1 \%)$ \\
$3^{\text {rd }}$ year & $34(13 \%)$ \\
$4^{\text {th }}$ year & $79(30.3 \%)$ \\
Last degree programme Grade & \\
A+ & $182(69.7 \%)$ \\
A & $13(5 \%)$ \\
B+ & $51(1.9 \%)$ \\
Didn't mentioned & \\
&
\end{tabular}


Table 2 is regarding academic activities; it is seen that $123(49.2 \%)$ students were satisfied with the regularity of the classes whereas only $101(39.7 \%)$ students were satisfied with availability of multimedia in the classroom. Table 2 Only 114 (44.4\%) students were satisfied with knowledge of their course coordinator. Though $113(43.5 \%)$ students were satisfied with extra consultation provided only $102(39.2 \%)$ students were satisfied with additional material provided by their course coordinator as presented in Table 3 .

Table 2. Student satisfaction with library, computerlab, sports, classroom and administrative support

\begin{tabular}{|c|c|c|c|c|c|}
\hline \multirow{2}{*}{ Variables } & \multicolumn{5}{|c|}{ Level of satisfaction } \\
\hline & SA & A & NS & $\mathrm{D}$ & SD \\
\hline \multicolumn{6}{|l|}{ Library facility } \\
\hline Satisfied with textbooks & $8(3.1 \%)$ & $44(16.9 \%)$ & $139(53.5 \%)$ & $38(14.6 \%)$ & $31(11.9 \%)$ \\
\hline Satisfied with research journals & $5(1.9 \%)$ & $31(11.9 \%)$ & $169(65 \%)$ & $29(11.2 \%)$ & $26(10 \%)$ \\
\hline Library timings & $4(1.6 \%)$ & $62(24 \%)$ & $142(55 \%)$ & $33(12.8 \%)$ & $17(6.6 \%)$ \\
\hline Facilities & $2(0.8 \%)$ & $54(20.9 \%)$ & $128(49.6 \%)$ & $51(19.8 \%)$ & $23(8.9 \%)$ \\
\hline Staff behavior & $4(1.6 \%)$ & $59(23.1 \%)$ & $137(53.7 \%)$ & $35(13.7 \%)$ & $20(7.8 \%)$ \\
\hline \multicolumn{6}{|l|}{ Computer lab facility } \\
\hline Satisfied with number of computers & $27(10.5 \%)$ & $152(59.1 \%)$ & $21(8.2 \%)$ & $32(12.5 \%)$ & $25(9.7 \%)$ \\
\hline Satisfied with internet speed & $35(13.6 \%)$ & $139(53.9 \%)$ & $18(7 \%)$ & $45(17.4 \%)$ & $21(8.1 \%)$ \\
\hline Lab attendant behavior & $17(6.6 \%)$ & $172(66.7 \%)$ & $24(9.3 \%)$ & $29(11.2 \%)$ & $16(6.2 \%)$ \\
\hline Computer lab timing & $21(8.1 \%)$ & $157(60.9 \%)$ & $21(8.1 \%)$ & $48(18.6 \%)$ & $11(4.3 \%)$ \\
\hline E-journals availability & $12(4.8 \%)$ & $80(31.7 \%)$ & $101(40.1 \%)$ & $48(19 \%)$ & $11(4.4 \%)$ \\
\hline \multicolumn{6}{|c|}{ Classroom and sports facilities and administrative support } \\
\hline Furniture in classroom & $18(7.1 \%)$ & $133(52.6 \%)$ & $7(2.8 \%)$ & $58(22.9 \%)$ & $37(14.6 \%)$ \\
\hline Air conditioner facility & $20(7.8 \%)$ & $125(49 \%)$ & $12(4.7 \%)$ & $56(22 \%)$ & $42(16.5 \%)$ \\
\hline Clerk staff behavior & $13(5.1 \%)$ & $89(35 \%)$ & $7(2.8 \%)$ & $76(29.9 \%)$ & $69(27.2 \%)$ \\
\hline College web site & $11(4.3 \%)$ & $116(45.7 \%)$ & $13(5.1 \%)$ & $72(28.3 \%)$ & $42(16.5 \%)$ \\
\hline Sports ground & $27(10.4 \%)$ & $157(60.6 \%)$ & $12(4.6 \%)$ & $45(17.4 \%)$ & $18(16.9 \%)$ \\
\hline Coaching Facilities & $8(3.1 \%)$ & $77(29.6 \%)$ & $52(20 \%)$ & $81(31.2 \%)$ & $42(16.2 \%)$ \\
\hline Sports equipment & $11(4.3 \%)$ & $77(29.8 \%)$ & $15(5.8 \%)$ & $101(39.1 \%)$ & $54(20.9 \%)$ \\
\hline Sports opportunities & $9(3.6 \%)$ & $100(39.7 \%)$ & $34(13.5 \%)$ & $78(31 \%)$ & $31(12.3 \%)$ \\
\hline
\end{tabular}

Table 3. Satisfaction with academic activities

\begin{tabular}{|c|c|c|c|c|c|c|c|}
\hline & OTT & MLT & MIT & OP & DT & HST & PS \\
\hline $\begin{array}{l}\text { Are you satisfied with course } \\
\text { coordinator? }\end{array}$ & $33(68.7 \%)$ & $21(56.7 \%)$ & $12(34.2 \%)$ & $12(52.1 \%)$ & $8(38 \%)$ & $8(47 \%)$ & $6(37.5 \%)$ \\
\hline $\begin{array}{l}\text { Are you satisfied with their lecture } \\
\text { delivery? }\end{array}$ & $29(63 \%)$ & $23(62 \%)$ & $15(42.8 \%)$ & $13(56.5 \%)$ & $9(42.8 \%)$ & $10(58.8 \%)$ & $8(50 \%)$ \\
\hline $\begin{array}{l}\text { Are you satisfied with research } \\
\text { activities? }\end{array}$ & $19(39.6 \%)$ & $12(32.4 \%)$ & $8(22.8 \%)$ & $7(30.4 \%)$ & $6(28.5 \%)$ & $5(29.4 \%)$ & $2(12.5 \%)$ \\
\hline $\begin{array}{l}\text { Are you satisfied with examination } \\
\text { procedure? }\end{array}$ & $16(33.3 \%)$ & $13(35.1 \%)$ & $6(17.1 \%)$ & $12(52.2 \%)$ & $5(23.8 \%)$ & $5(29.4 \%)$ & $4(25 \%)$ \\
\hline $\begin{array}{l}\text { Are you satisfied with teacher's } \\
\text { respect to students }\end{array}$ & $42(87.5 \%)$ & $28(75.7 \%)$ & $22(62.8 \%)$ & $14(60.9 \%)$ & $19(86.3 \%)$ & $11(61.1 \%)$ & $10(62.5 \%)$ \\
\hline $\begin{array}{l}\text { Are you satisfied with teacher's } \\
\text { attitude towards class }\end{array}$ & $36(75 \%)$ & $22(59.4 \%)$ & $16(45.7 \%)$ & $13(56.5 \%)$ & $11(50 \%)$ & $12(66.7 \%)$ & $7(43.7 \%)$ \\
\hline $\begin{array}{l}\text { Are you satisfied with course } \\
\text { coordinator? }\end{array}$ & $29(63 \%)$ & $23(62 \%)$ & $15(42.8 \%$ & $12(52.1 \%)$ & $8(38 \%)$ & $8(47 \%)$ & $6(37.5 \%)$ \\
\hline
\end{tabular}

\section{DISCUSSION}

Our study showed that only $58(22.1 \%)$ students were satisfied with their program with $116(77.9 \%)$ students were not willing to recommend this program. The highest level of recommendation observed in discipline of speech therapy whereas the lowest level of recommendation was observed in students of dental technology. Figure 1 shows the result of student satisfaction survey conducted in 2012 among physiotherapy under and postgraduate students enrolled at different institutes of Pakistan showed 60.8\% student satisfaction [4]. Ali et al. studied key factors for determining student satisfaction in distance learning courses at Allama Iqbal Open University and revealed that student satisfaction is positively and significantly correlated with student-instructor interaction [6]. Major factor in our study ascribing to high student dissatisfaction with their program could be unwillingness to take this program as most of the students opt their discipline only because they couldn't get admission in medicine. Other factors included weaknesses and flaws in the program, family influences, social image of allied health professional and discontentment with teaching methodologies and curriculum. This is in contrast to data published by Barfield et al. in 2011 which determined personal and social influences, academic preparation, career opportunity, individual aspiration and self-efficacy as major contributing factors associated with enrolment in allied health sciences [7]. 
Another study revealed that dental public health program me had met the expectation of $92 \%$ of the respondents [8]. Percentage of students recommending their program was $70.7 \%$.

However, results of our study were close to the findings of a study conducted by Hakim et al. regarding nursing students' satisfaction about their field of study as she observed that $83.3 \%$ of the nursing students had little satisfaction as to the situation of educational environment [9]. The library of the university should facilitate the provision of updated textbooks, online specific research journals, magazines and other electronic resources. Knapp and subsequent investigators proved that course work, class level, gender, scholastic standing, and level of awareness of library services may affect college library use [10]. Another study proved that the library facilities mostly used were for essential texts, e-mail, PCs and study facilities whereas computer Aided Learning packages, journals and video facilities were least used [11]. In our study, only $20.9 \%$ of the students agreed to the provision of library facilities. Satisfaction regarding availability of textbooks and research journals were $16.9 \%$ and $11.9 \%$ respectively. Key factor attributing to decreased use and less frequent visits could be non-availability of latest editions of textbooks and lack of online resources and journals.

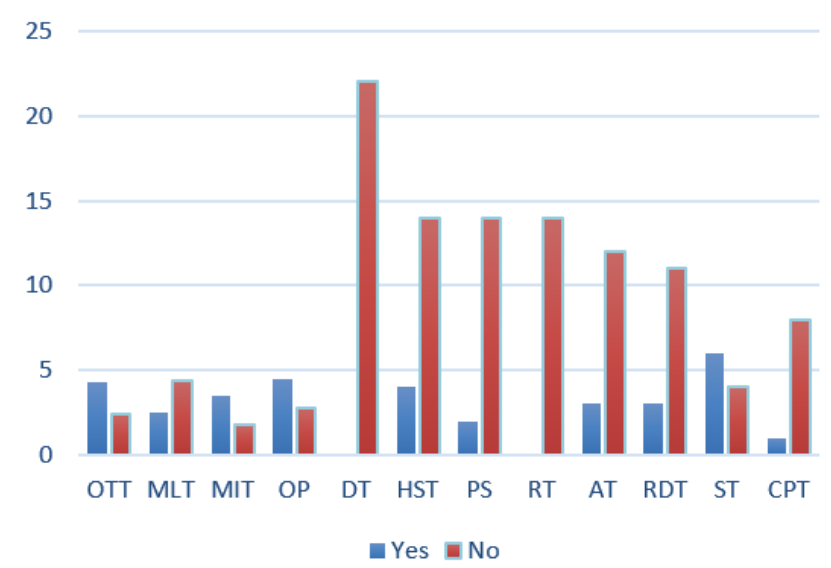

*OTT-Operation theatre technology, MLT-Medical laboratory technologist, MIT-Medical imaging technology, OP-Orthotics and Prosthetics, DT-Dental technology, HST-Hearing Sciences Technology, PS -Psychological Sciences, RT-Radiation Therapy technology, AT-Anesthesia Technology, RDT-Renal Dialysis Technology, ST-Speech Therapy Technology, CPT-Cardiac Perfusion Technology

Figure 1. Difference of program recommendation among different disciplines

The results regarding usage of computer lab services were more encouraging with $91.9 \%$ of students being aware of the computer lab location and $59.1 \%$ frequently visiting the computer lab. A total of $66.7 \%$ of the student agreed to the cooperative behavior of staff at the computer lab. The main reasons for regular visits and high satisfaction with computer lab could be surfing the internet to find information for learning/research and attending courses/workshops/seminars. Sadoon and Liong studied the perception of students on services at the computer laboratory at a school of mathematical sciences at Malaysia, revealing that $62.9 \%$ of the students were regularly visiting the computer lab [12]. Saleh et al. compared the two different computer layout and analyzed the perception of students on physical environment in computer lab [13].

According to Okon, classroom is a place where teachers organize their work, carry out educational plans as well as provides a suitable environment where research findings are tested or tried out [14]. To promote a proper atmosphere for effective teaching and learning, the physical environment of the classroom must be harnessed. The physical environment is made up of desks, chairs, tables, space, instructional materials, lighting and ventilation as well as the latest information communication technology (ICT) equipment and library. The availability and state of the classroom plays a key role in facilitating or engendering the teaching-learning process [15]. Our results indicated that $52.6 \%$ of the participants satisfied with the furniture facility and $49 \%$ satisfied with the availability of air conditioner. Whereas agreement regarding regular classes and multimedia availability was $49.2 \%$ and $22.4 \%$ respectively. Sulaiman and Hussain studied effects of classroom physical environment on the academic achievement scores of secondary school students in Kohat division of Pakistan. They showed that students who were provided with a suitable physical environment in the classroom, performed much better than the control group [16].

The results of a study conducted by Ravenswood, et al. indicated that characteristics of administrative support significantly correlated with intent to stay in the field, extent of support, opportunities for growth, appreciation and trust, job satisfaction and positive views of their school [17]. Yet in our study, 
only $35 \%$ of the students were satisfied with the behavior of clerical staff regarding student affairs. Hardlein and Zurner emphasized the need for improved internal communication at the university [18].

Satisfaction of students regarding teaching methodology, level of knowledge of teachers and their attitude and respect towards students was bit encouraging but they emphasized the need to have outside the classroom teaching consultation, provision of additional teaching material and collection of feedback responses from students. Machado, et al. [19] concluded that students would also prefer improved access to interactions with faculty outside the classroom as well as quality academic advising. They also suggested that being involved in social aspects as well as the academic realm retains students and an institution must recognize "that the social dimension in learning activities is critical".

There was little satisfaction regarding examination process and provision of research facilities in our study. Ziaee, et al. evaluated student satisfaction with the ways they are tested. They found a positive association between overall satisfaction and satisfaction with the methods through which their abilities were assessed [20]. Hakim also indicated in her research that most students had little satisfaction concerning the method of clinical education by trainers [9].

Simulation training is crucial as far as the student satisfaction and the skills, including confidence, knowledge, and grooming of the students is concerned [21-23]. Studies show that the learning environment closely related to the real-life demonstration improves the learning capacity of the students. In turn, students feel more satisfied with the learning environment [24]. The learning environment has a direct relationship with the academic performance of the students. Many medical educationists emphasize the practice of simulation training methods to be employed in educational institutes throughout the world [25, 26]. The advancements in research medical education have been improved by the practice of modern educational models. For instance, blended learning models [27]. These models are based on the use of electronic and online learning resources in addition to orthodox lesson-based classroom learning. Blended models enable students to access online databases for audio-visual illustrations to clarify their concepts. Cross-sectional surveys evaluating student satisfaction levels and academic performance reveal that blended learning enhances students' exam performance and their clinical practice expertise [28]. The flipped classroom is a strategy utilized in blended models of learning in which the instructor can address students' queries and difficulties by accessing online lectures and learning exercises in the classroom [29]. The effectiveness of blended and flipped learning models has been established in several research studies. Simulation training of the instructors and the use of practical illustrations increases satisfaction among medical students [21, 30].

\section{CONCLUSION}

Student's emotional, psychological, accommodation problems, and curriculum satisfaction can be considered as limitations of this study. Administrative support could have been much more explained but it was outside the reach of researcher. However, in future, more elaborative studies can be conducted on provision of research facilities, reasons for dissatisfaction with the program, concerns over program cost and satisfaction with the existing curriculum according to international standards. Students of other existing undergraduate programs can also be involved in future studies. As satisfaction of students with their program and other parameters and level of recommendation was very low, it's the prime responsibility of institute to consider student satisfaction as a tool to improve quality education and develop a reasonable environment to meet higher expectations of students and earn a good reputation.

\section{REFERENCES}

[1] Talegeta S, Worku T, Gemechu A., "Service Quality Nexus Students' Satisfaction at Ambo University Selected Campuses, Ethiopia," Journal of Science and Sustainable Development, vol. 6, no. 1, pp. 71-86, 2018.

[2] Saleem A., Saghir A., Akhtar R. N., et al., "Students' Satisfaction Regarding Higher Education: A Survey Study in Azad Kashmir, Pakistan,” Science International (Lahore), vol. 24, pp. 91-94, 2012.

[3] Ijaz A., Irfan S., Shahbaz S., et al., "An empirical model of student satisfaction: Case of Pakistani public sector business schools," Journal of Quality and Technology Management, vol. 7, no. 2, pp. 91-114, 2011.

[4] Bhatti Z M. J. A., "Evaluation of overall satisfaction level among the students of physiotherapy (undergraduates \& post graduates) enrolled in different physiotherapy institute of the Pakistan," International Journal of Rehabilitation Sciences, vol. 01, no. 02, pp. 36-42, 2012.

[5] Anderson M. M., Shelledy D. C., "Predictors of student satisfaction with their allied health sciences program courses," Journal of Allied Health, vol. 42, no. 2, pp. 92-98, 2013.

[6] Ali A., Ahmed I., "Key factors for determining students' satisfaction in distance learning courses. A study of Allama Iqbal Open University," Contemporary Education Technology, vol. 2, no. 2, pp. 118-134, 2011.

[7] Barfield J. P., Folio M. R., Lem E. T., Zhang J. J., "Factors associated with enrollment in allied health education programs: development of a predictive scale," Journal of Allied Health, vol. 40, no. 2, pp. 82-89, 2011. 
[8] Kahlon J., Delgado-Angolu E. K. and Bernabe E., "Graduates' satisfaction with and attitudes towards a master programe in dental public health," BMC Medical Education, vol. 61, no. 15, pp. 2-7, 2015.

[9] Hakim A., "Nursing students' satisfaction about their field of study," Journal of Advances in Medical Education and Profession, vol. 2, no. 2, pp. 82-87, 2014.

[10] KNAPP P. B., "College teaching and the college library," Chicago: American Library Association, 1959.

[11] Martin S., "Impact of a graduate entry programme on amedical school library service," Journal of Health Information and Libraries, vol. 20, no. 1, pp. 42-49, 203

[12] Sadoon S. and Liong C. Y., "Perception of students on services at the computer library: a case study at the school of mathmetical sciences, University of Kebangsaan Malaysia," Procedia Social and Behavioural Sciences, vol. 59, pp. 117-124, 2012.

[13] Salleh N., Mohd Ayub A. F. and Zainal Abidin N., "Perception of students on physical environment of computer laboratory: Comparison of two different computer layout," Journal of Techno-Social, vol. 1, no. 2, pp. 59-74, 2010.

[14] Okon J. E. and Sole M. A., "Management of the Nigerian primary school plant: perceptions for effective practice," Nigerian Journal of Curriculum and Studies, vol. 13, no. 1, pp. 139-146, 2006.

[15] Ahunanya S. I. and Ubabudu M. C. M., "Enrolment, facilities and financial allocation in Lagos state higher education: implication for quality graduates," Nigerian Journal of Educational Administration and Planning, vol. 6, no. 1, pp. 153-164, 2006.

[16] Sulaiman Q. and Hussain I., "Effects of classroom physical environment on the academic achievement scores of secondary school students in Kohat division, Pakistan," International Journal of Learning and Development, vol. 4, no. 1, pp. 71-82, 2014.

[17] Ravenswood K., Douglas J., Haar J., "Physical and verbal abuse, work demands, training and job satisfaction amongst aged-care employees in the home and community sector," Labour \& Industry: a Journal of The Social and Economic Relations of Work, vol. 27, no. 4, pp. 302-318, 2017.

[18] Herdlein R. and Zurner E., "Student satisfaction, need and learning outcomes: A case study approach at a European university," SAGE Open, vol. 2, pp. 1-10, 2015

[19] Machado M. L., Brites R., Magalhães A. and Sá M. J., "Satisfaction with higher education: Critical data for student development," European Journal of Education, vol. 46, no. 3, pp. 415-432, 2011.

[20] Ziaee V., Ahmednijad Z. and Morravedji J. R., "An evaluation on medical students' satisfaction with clinical education and its effective factors," Medical Education Online, vol. 9, no. 1, pp. 4365-4371, 2004.

[21] Alanazi A. A., Nicholson N., Thomas S., "The use of simulation training to improve knowledge, skills, and confidence among healthcare students: a systematic review," The Internet Journal of Allied Health Sciences and Practice, vol. 15, no. 3, pp. 1-20, 2017.

[22] Liaw S. Y., Scherpbier A., Rethans J. J., Klainin-Yobas P., “Assessment for simulation learning outcomes: a comparison of knowledge and self-reported confidence with observed clinical performance," Nurse education today, vol. 32, no. 6, pp. e35-39, 2012.

[23] Kiernan L. C., "Evaluating competence and confidence using simulation technology," Nursing, vol. 48, no. 10, pp. 45-52, 2018.

[24] Kangas M., Siklander P., Randolph J., Ruokamo H., "Teachers' engagement and students' satisfaction with a playful learning environment," Teaching and Teacher Education, vol. 63, pp. 274-284, 2017.

[25] Phillips K. F., Mathew L., Aktan N., Catano B., "Clinical education and student satisfaction: an integrative literature review," International journal of nursing sciences, vol. 4, no. 2, pp. 205-213, 2017.

[26] Martin F., Bolliger D U., "Engagement matters: Student perceptions on the importance of engagement strategies in the online learning environment," Online Learning, vol. 22, no. 1, pp. 205-222, 2018.

[27] Mourad A., Jurjus A., Hussein I. H., "The what or the how: a review of teaching tools and methods in medical education," Medical Science Educator, vol. 26, no. 4, pp. 723-728, 2016.

[28] Shimizu I., Nakazawa H., Sato Y., Wolfhagen I. H., Könings K. D., "Does blended problem-based learning make Asian medical students active learners?: a prospective comparative study," BMC Medical Education, vol. 19, no. 1, pp. 1-9, 2019.

[29] Street S. E., Gilliland K. O., McNeil C., Royal K., "The flipped classroom improved medical student performance and satisfaction in a pre-clinical physiology course," Medical Science Educator, vol. 25, no. 1, pp. 35-43, 2015.

[30] Dang Y. M., Zhang Y. G., Ravindran S., Osmonbekov T., "Examining student satisfaction and gender differences in technology-supported, blended learning," Journal of Information Systems Education, vol. 27, no. 2, p. 119, 2016. 